\title{
Communication
}

\section{Human-Like Neutralizing Antibodies Protect Mice from Aerosol Exposure with Western Equine Encephalitis Virus}

\author{
Crystal W. Burke ${ }^{1}$, Jeffrey W. Froude ${ }^{1,+}$, Sebastian Miethe ${ }^{2}$, Birgit Hülseweh ${ }^{3}$, \\ Michael Hust ${ }^{2,4}$ (i) and Pamela J. Glass ${ }^{1, *}$ \\ 1 United States Army Medical Research Institute for Infectious Diseases, Fort Detrick, MD 21702, USA; \\ crystal.w.burke.ctr@mail.mil (C.W.B.); jeffrey.w.froude2.mil@mail.mil (J.W.F.) \\ 2 Technische Universität Braunschweig, Institut für Biochemie, Biotechnologie und Bioinformatik, \\ Spielmannstr.7, 38106 Braunschweig, Germany; miethe.sem@icloud.com (S.M.); m.hust@tu-bs.de (M.H.) \\ 3 Wehrwissenschaftliches Institut für Schutztechnologien (WIS)_ABC-Schutz, Humboldtstr. 1, \\ 29623 Munster, Germany; BirgitHuelseweh@bundeswehr.org \\ 4 YUMAB GmbH, Science Campus Braunschweig Süd, Inhoffenstr.7, 38124 Braunschweig, Germany \\ * Correspondence: pamela.j.glass.civ@mail.mil; Tel.: +1-301-619-4742 \\ + Current address: Defense Threat Reduction Agency, Vaccine and Therapeutics Division, Fort Belvoir, \\ VA 22060, USA
}

Received: 14 February 2018; Accepted: 22 March 2018; Published: 24 March 2018

\begin{abstract}
Western equine encephalitis virus (WEEV) causes symptoms in humans ranging from mild febrile illness to life-threatening encephalitis, and no human medical countermeasures are licensed. A previous study demonstrated that immune serum from vaccinated mice protected against lethal WEEV infection, suggesting the utility of antibodies for pre- and post-exposure treatment. Here, three neutralizing and one binding human-like monoclonal antibodies were evaluated against WEEV aerosol challenge. Dose-dependent protection was observed with two antibodies administered individually, ToR69-3A2 and ToR68-2C3. In vitro neutralization was not a critical factor for protection in this murine model, as ToR69-3A2 is a strong neutralizing antibody, and ToR68-2C3 is a non-neutralizing antibody. This result highlights the importance of both neutralizing and non-neutralizing antibodies in the protection of mice from WEEV lethality.
\end{abstract}

Keywords: western equine encephalitis virus (WEEV); alphavirus; monoclonal antibody (mAb); scFv-Fc; NHP antibodies; passive vaccine; aerosol challenge; antibody engineering

\section{Introduction}

The single-stranded positive-sense RNA virus, western equine encephalitis virus (WEEV), is a member of the Togaviridae family [1]. WEEV is a natural chimera resulting from the recombination of eastern equine encephalitis virus (EEEV) and Sindbis virus (SINV) [2]. In humans, WEEV, EEEV and Venezuelan equine encephalitis virus (VEEV) cause disease symptoms ranging from a mild febrile illness to severe encephalitis that may lead to mortality [1]. Disease severity is influenced by multiple factors including viral strain, dose and route of inoculation, as well as health status and age of the patient [1,3-5]. WEEV has caused sporadic outbreaks in horses and humans [6-8]. Most recently, an outbreak in Uruguay in 2009 resulted in a fatal human case [9]. Disease severity coupled with the ease of production and dissemination of the encephalitic alphaviruses has resulted in these agents designated as Category B pathogens and highlights the need to develop effective medical countermeasures in the event of a biological attack. Other arboviruses, such as chikungunya 
and Zika virus, have demonstrated rapid shifts in disease prevalence causing widespread epidemics, demonstrating the importance of preparation for potentially emerging infectious diseases.

The pursuit for a vaccine that is safe and efficacious against alphavirus exposure has revealed an essential role of antibodies in the control of virus infection [10-13]. Furthermore, the level of neutralizing antibody response elicited by a vaccine candidate often determines its continued development. Passive transfer of hyperimmune serum from WEEV-vaccinated animals into naïve recipients was protective [13-15], making the use of antibody therapeutics attractive as a rapidly deployable medical countermeasure. For this reason, monoclonal antibodies against other alphaviruses, including VEEV [16] and Semliki Forest virus [17], have been under development since the 1980s. Humanized murine $[16,18]$, nonhuman primate (NHP) $[19,20]$, as well as human [21] antibodies have been developed as potential medical countermeasures.

Previously, four human-like antibodies were identified from immune antibody gene libraries constructed from inactivated WEEV-vaccinated macaques [19]. While all four antibodies bound WEEV antigen by ELISA, only three of the four had varying degrees of WEEV neutralizing activity in an in vitro assay. Here, the ability of these four WEEV-specific monoclonal antibodies to protect mice from a lethal WEEV aerosol exposure was examined.

\section{Materials and Methods}

\subsection{Ethics Statement and Animal Care}

Research was conducted under a USAMRIID Institute Animal Care and Use Committee-approved protocol (9 May 2016) in compliance with the Animal Welfare Act, Public Health Service Policy, and other Federal statutes and regulations relating to animals and experiments involving animals. The USAMRIID is accredited by the Association for Assessment and Accreditation of Laboratory Animal Care, International, and adheres to principles stated in the Guide for the Care and Use of Laboratory Animals, National Research Council, 2011.

\subsection{Antibody Preparation}

The antibodies ToR68-2C3, ToR68-2E9, ToR68-3G2 and ToR69-3A2 were produced as scFv-Fc with a human Fc part as described previously [22].

\subsection{Virus Stock}

The WEEV Fleming stock was obtained from the World Reference Center for Emerging Viruses and Arboviruses (Galveston, TX). The stock was amplified three times in Vero cells from a lyophilized stock that had undergone five passages through suckling mouse brain.

\subsection{In Vivo WEEV Challenge}

Specific pathogen-free, eight-week-old BALB/c mice ( $n=10$ /group; Charles River Laboratories) were utilized as a model for WEEV infection. Mice received a single inoculation of monoclonal antibody, irrelevant anti-Marburg virus $(100 \mu \mathrm{g})$ antibody [23] or PBS intraperitoneally approximately $24 \mathrm{~h}$ prior to challenge. Based on previous $\mathrm{LD}_{50}$ studies, mice were exposed to a target inhaled dose of $1 \times 10^{3}$ PFU by the aerosol route using the Automated Bioaerosol Exposure System (ABES) II, inside a Class III biological safety cabinet. All mice were weighed on Days 1-14 after challenge and were monitored daily throughout the study for clinical signs of disease.

\section{Results}

\section{WEEV mAb Prophylaxis in Mice}

ToR68-2C3, ToR68-2E9, ToR68-3G2 and ToR69-3A2 were previously identified to have WEEV binding activity [19]. Additionally, ToR68-2E9, ToR68-3G2 and ToR69-3A2 neutralized WEEV, 
while ToR68-2C3 did not [19]. To examine the ability of these mAbs to protect mice from WEEV exposure, BALB/c mice ( $n=10$ /group) were administered a single-dose of decreasing concentrations (200 $\mu \mathrm{g}-10 \mu \mathrm{g}$ per mouse) of the mAbs by the intraperitoneal (i.p.) route. Approximately $24 \mathrm{~h}$ after $\mathrm{mAb}$ administration, mice were exposed by the aerosol route to a target inhaled dose of $1 \times 10^{3} \mathrm{PFU}$ of the WEEV Fleming strain [24]. Mice were monitored for clinical signs of disease and were euthanized when moribund. As expected, an aerosol challenge with WEEV Fleming resulted in rapid weight loss (Figure 1A) and disease progression with signs of neurological disease including hyper-reactivity and circling (Figure 1B). By five days post-exposure, 100\% lethality was observed with an average survival time of four days for mice administered PBS or irrelevant $\mathrm{mAb}$ (Figure 2). Two of the neutralizing mAbs, ToR68-3G2 and ToR68-2E9 provided no significant protection from the lethal WEEV aerosol exposure with an average survival time (AST) of four days for all dose groups (Figure 2A,B). A dose-dependent increase in survival was observed for the neutralizing ToR69-3A2 mAb with a $90 \%$ survival rate at the 200- $\mu \mathrm{g}$ dose and a 50\% survival rate at the lowest dose (10 $\mu \mathrm{g}$; Figure $2 \mathrm{C})$. Somewhat surprisingly, treatment with the non-neutralizing Tor68-2C $3 \mathrm{mAb}$ resulted in $60 \%$ survival at the highest dose tested (Figure 2D), and the level of protection observed with this non-neutralizing mAb was dose-dependent. Both ToR69-3A2 and ToR68-2C3 reduced or eliminated clinical signs of disease (Figure 1B).

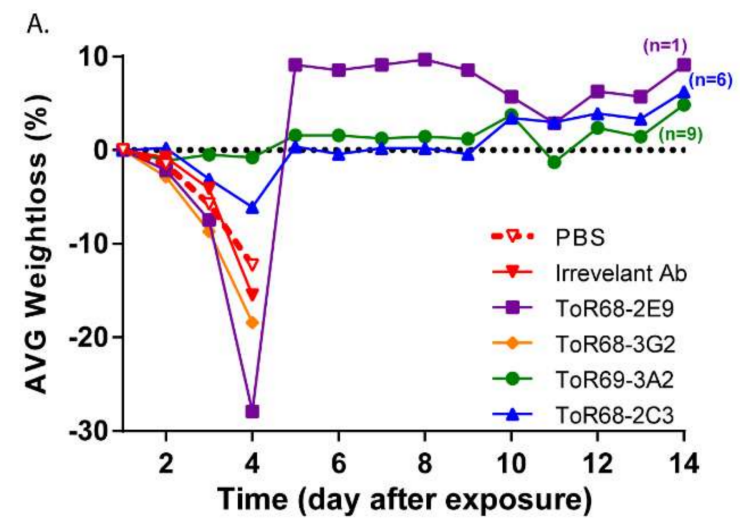

B.

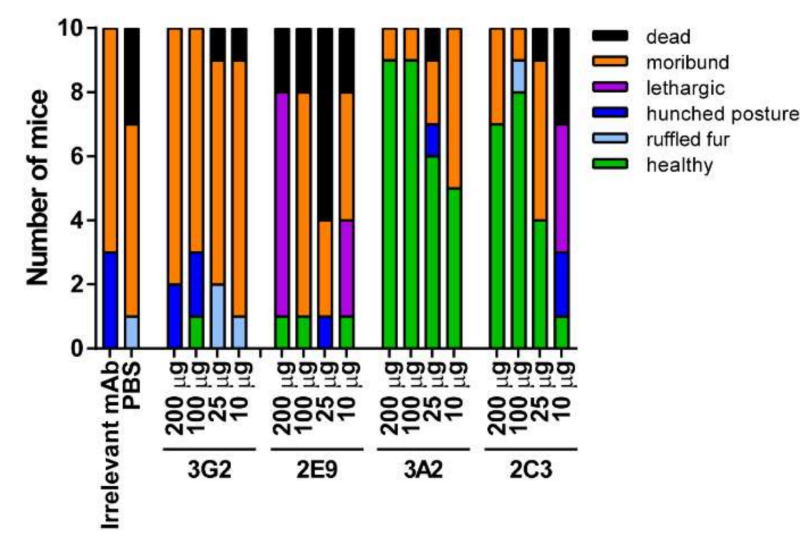

Figure 1. Morbidity of mice treated with anti-western equine encephalitis virus (WEEV) monoclonal antibodies following WEEV exposure. (A) Cohorts of 10 mice were administered $200 \mu \mathrm{g} / \mathrm{mouse}$ of ToR68-2E9 (purple), ToR68-2C3 (blue), ToR69-3A2 (green), Tor68-3G2 (orange), irrelevant anti-Marburg virus (100 $\mathrm{gg} /$ mouse; solid red) mAb per mouse or an equivalent volume of PBS (dashed red) mAb i.p. $24 \mathrm{~h}$ prior to aerosol exposure to WEEV Fleming ( $\left.10^{3} \mathrm{PFU}\right)$. Mice were weighed daily, and the percent weight loss was determined by comparison to pre-challenge day weights. (B) Clinical observations were made twice daily. Mice were moribund when displaying neurological signs of disease or were unresponsive to stimulus. Data shown are the clinical signs observed on Day 4 (average survival day) post-exposure. 


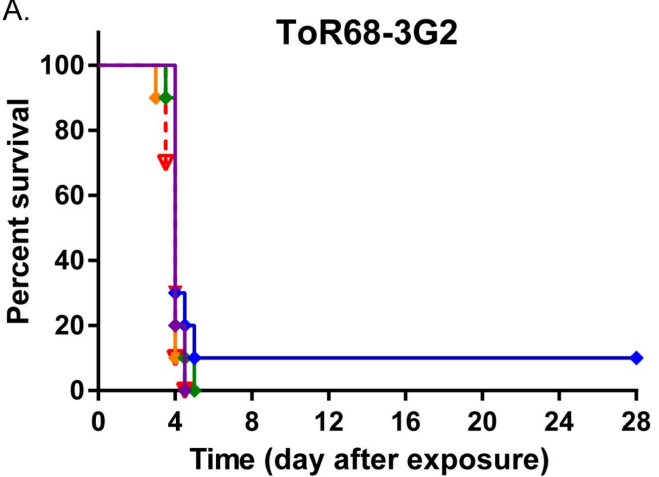

C.

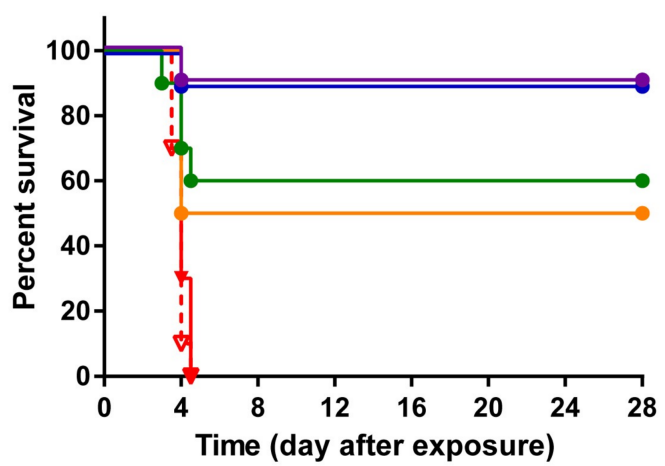

B.

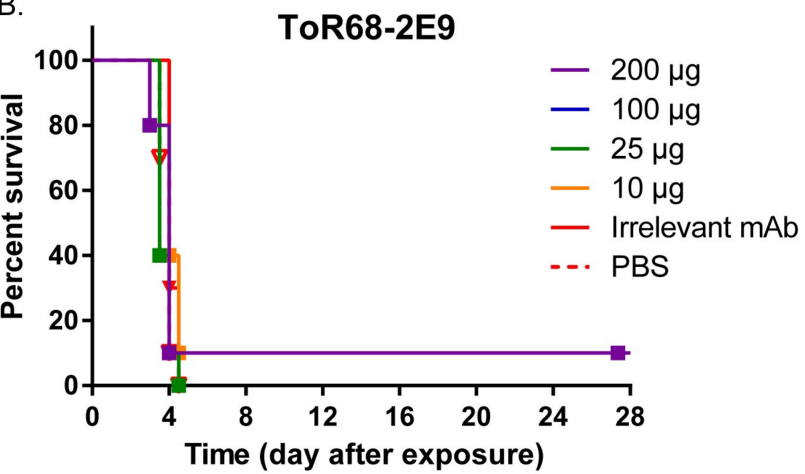

D.

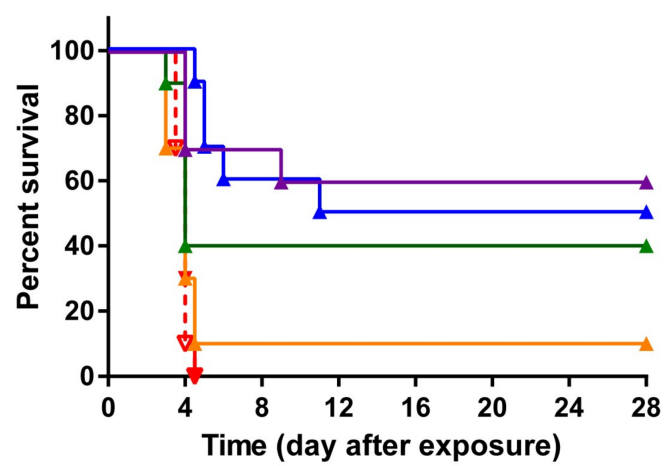

Figure 2. Mortality of mice treated with anti-WEEV monoclonal antibodies following WEEV exposure. (A) Mice administered ToR68-3G2. (B) Mice administered ToR68-2E9. (C) Mice administered ToR69-3A2. (D) Mice administered ToR68-2C3. Cohorts of 10 mice were administered $200 \mu \mathrm{g}$ (purple), $100 \mu \mathrm{g}$ (blue), $25 \mu \mathrm{g}$ (green), $10 \mu \mathrm{g}$ (orange) mAb per mouse, $100 \mu \mathrm{g}$ irrelevant anti-Marburg virus (solid red) $\mathrm{mAb}$ per mouse or an equivalent volume of PBS (dashed red) i.p. $24 \mathrm{~h}$ prior to aerosol exposure to WEEV Fleming ( $\left.10^{3} \mathrm{PFU}\right)$. Mice were observed twice daily for clinical signs of disease and humanely euthanized when moribund.

\section{Discussion}

Anti-WEEV immune serum from rabbits [23], mice [14] and NHPs [25] passively administered to mice can protect against lethal WEE disease. However, to date, no neutralizing or protective murine, human or human-like anti-WEEV monoclonal antibodies have been identified [26]. Here, we demonstrated the first use of a monoclonal antibody prophylaxis to protect mice challenged by a lethal WEEV aerosol exposure. Importantly, protection was observed with a single dose of either a neutralizing antibody ToR69-3A2 or a non-neutralizing antibody ToR68-2C3. Non-neutralizing monoclonal antibodies have demonstrated some success in mouse protection studies against other alphaviruses, including Sindbis virus [27], Semliki Forest virus [17] and VEEV [20,28]. The mechanism of action of ToR68-2C3 is undefined, but protection may be attributed to complement-mediated lysis or antibody-dependent cell-mediated lysis of infected cells $[29,30]$. Together, these data highlight the importance of in vivo evaluation of both neutralizing and non-neutralizing monoclonal antibodies for protective efficacy.

Despite efforts in antibody identification against alphaviruses, this is the first report of a monoclonal antibody that protected mice against a WEEV challenge. In vaccination studies delivering WEEV, EEEV and VEEV antigen concomitantly, WEEV antigens appear to be less immunogenic in comparison to VEEV and EEEV antigens. This is evidenced by lower neutralizing and binding antibody titers to WEEV vaccine components when similar protein concentrations are delivered in a trivalent formulation [25,31]. Alternatively, the reduced immunogenicity of WEEV antigen 
in these studies may be a result of immunologic interference similar to what was observed in humans after sequential alphavirus vaccine administration [32,33]. Despite the potential lower WEEV immunogenicity, the vaccines tested protected $100 \%$ of mice, suggesting the combination of neutralizing and binding antibodies could be important to confer protection. In comparison to the other encephalitic alphaviruses, WEEV's reduced protein immunogenicity may contribute to the difficulty of identifying a single WEEV monoclonal antibody that is completely protective.

Neither antibody provided 100\% protection from lethality after WEEV aerosol exposure even at the $200 \mu \mathrm{g}$ dose. Studies with passive administration of immune serum from NHPs [25,34] and transchromosomic bovine IgG [35] into mice have found that a single administration was not $100 \%$ protective against a high dose aerosol exposure of VEEV [35], EEEV or WEEV [25,34]; however, delivery of a second administration resulted in $90-100 \%$ survival. This would suggest that a second administration of ToR69-3A2 or ToR68-2C3 may result in enhanced survival. Another possibility is the generation of antibody-escape mutants, which have been identified for other viruses including Ebola virus [36], Dengue virus [37] and influenza virus [38], as well as alphaviruses [39,40]. Therefore, future studies will evaluate this possibility and also the efficacy of a cocktail of ToR69-3A2 and ToR68-2C3 for enhanced survival benefits.

To summarize, this manuscript describes the first monoclonal antibodies that are protective against WEEV in a mouse in vivo aerosol challenge model.

Acknowledgments: We thank Christina Gardner for her careful review of the manuscript. This work was funded by the Joint Science and Technology Office for Chemical and Biological Defense Program CB3957. The opinions, interpretations, conclusions and recommendations are those of the author and are not necessarily endorsed by the U.S. Army.

Author Contributions: Crystal W. Burke, Jeffrey W. Froude and Pamela J. Glass conceived of and designed the experiments. Crystal W. Burke and Jeffrey W. Froude performed the experiments. Crystal W. Burke, Jeffrey W. Froude and Pamela J. Glass analyzed the data. Michael Hust, Sebastian Miethe, Birgit Hülseweh and Pamela J. Glass contributed reagents/materials/analysis tools. Crystal W. Burke wrote the paper.

Conflicts of Interest: The authors declare no conflict of interest. The funding sponsors had no role in the design of the study; in the collection, analyses or interpretation of data; in the writing of the manuscript; nor in the decision to publish the results.

\section{References}

1. Griffin, D.E. Alphaviruses. In Fields' Virology, 5th ed.; Knipe, D.M., Howley, P.M., Eds.; Lippincott Williams \& Wilkins: Philadelphia, PA, USA, 2007; pp. 1023-1067.

2. Hahn, C.S.; Lustig, S.; Strauss, E.G.; Strauss, J.H. Western equine encephalitis virus is a recombinant virus. Pro. Nat. Acad. Sci. USA 1988, 85, 5997-6001. [CrossRef]

3. Zacks, M.A.; Paessler, S. Encephalitic alphaviruses. Vet. Microbiol. 2010, 140, 281-286. [CrossRef] [PubMed]

4. Calisher, C.H. Medically important arboviruses of the united states and canada. Clin. Microbiol. Rev. 1994, 7, 89-116. [CrossRef] [PubMed]

5. Leitenberg, M. Biological weapons in the twentieth century: A review and analysis. Crit. Rev. Microbiol. 2001, 27, 267-320. [CrossRef] [PubMed]

6. Current Trends Arboviral Infections of the Central Nervous System-United States. 1987. Available online: https: / / www.cdc.gov/mmwr/preview/mmwrhtml/00001082.htm (accessed on 13 February 2018).

7. Potter, M.E.; Currier, R.W.; Pearson, J.E.; Harris, J.C.; Parker, R.L. Western equine encephalomyelitis in horses in the northern red river valley, 1975. J. Am. Vet. Med. Assoc. 1977, 170, 1396-1399. [PubMed]

8. Leake, J. Epidemic of infectious encephalitis. Public Health Rep. 1941, 56, 1902-1905. [CrossRef]

9. Delfraro, A.; Burgueno, A.; Morel, N.; Gonzalez, G.; Garcia, A.; Morelli, J.; Perez, W.; Chiparelli, H.; Arbiza, J. Fatal human case of western equine encephalitis, uruguay. Emerg. Infect. Dis. 2011, 17, 952-954. [CrossRef] [PubMed]

10. Lum, F.M.; Teo, T.H.; Lee, W.W.; Kam, Y.W.; Renia, L.; Ng, L.F. An essential role of antibodies in the control of chikungunya virus infection. J. Immunol. 2013, 190, 6295-6302. [CrossRef] [PubMed]

11. Griffin, D.E.; Ubol, S.; Despres, P.; Kimura, T.; Byrnes, A. Role of antibodies in controlling alphavirus infection of neurons. Curr. Top. Microbiol. Immunol. 2001, 260, 191-200. [PubMed] 
12. Levine, B.; Hardwick, J.M.; Trapp, B.D.; Crawford, T.O.; Bollinger, R.C.; Griffin, D.E. Antibody-mediated clearance of alphavirus infection from neurons. Science 1991, 254, 856-860. [CrossRef] [PubMed]

13. Rico, A.B.; Phillips, A.T.; Schountz, T.; Jarvis, D.L.; Tjalkens, R.B.; Powers, A.M.; Olson, K.E. Venezuelan and western equine encephalitis virus e1 liposome antigen nucleic acid complexes protect mice from lethal challenge with multiple alphaviruses. Virology 2016, 499, 30-39. [CrossRef] [PubMed]

14. Phillips, A.T.; Schountz, T.; Toth, A.M.; Rico, A.B.; Jarvis, D.L.; Powers, A.M.; Olson, K.E. Liposome-antigen-nucleic acid complexes protect mice from lethal challenge with western and eastern equine encephalitis viruses. J. Virol. 2014, 88, 1771-1780. [CrossRef] [PubMed]

15. Wu, J.Q.; Barabe, N.D.; Chau, D.; Wong, C.; Rayner, G.R.; Hu, W.G.; Nagata, L.P. Complete protection of mice against a lethal dose challenge of western equine encephalitis virus after immunization with an adenovirus-vectored vaccine. Vaccine 2007, 25, 4368-4375. [CrossRef] [PubMed]

16. Roehrig, J.T.; Mathews, J.H. The neutralization site on the e2 glycoprotein of venezuelan equine encephalomyelitis (TC-83) virus is composed of multiple conformationally stable epitopes. Virology 1985, 142, 347-356. [CrossRef]

17. Boere, W.A.; Benaissa-Trouw, B.J.; Harmsen, M.; Kraaijeveld, C.A.; Snippe, H. Neutralizing and non-neutralizing monoclonal antibodies to the e2 glycoprotein of semliki forest virus can protect mice from lethal encephalitis. J. Gen. Virol. 1983, 64, 1405-1408. [CrossRef] [PubMed]

18. Hu, W.G.; Phelps, A.L.; Jager, S.; Chau, D.; Hu, C.C.; O'Brien, L.M.; Perkins, S.D.; Gates, A.J.; Phillpotts, R.J.; Nagata, L.P. A recombinant humanized monoclonal antibody completely protects mice against lethal challenge with venezuelan equine encephalitis virus. Vaccine 2010, 28, 5558-5564. [CrossRef] [PubMed]

19. 1Hulseweh, B.; Rulker, T.; Pelat, T.; Langermann, C.; Frenzel, A.; Schirrmann, T.; Dubel, S.; Thullier, P.; Hust, M. Human-like antibodies neutralizing western equine encephalitis virus. MAbs 2014, 6, 718-727.

20. Rulker, T.; Voss, L.; Thullier, P.; LM, O.B.; Pelat, T.; Perkins, S.D.; Langermann, C.; Schirrmann, T.; Dubel, S.; Marschall, H.J.; et al. Isolation and characterisation of a human-like antibody fragment (SCFV) that inactivates veev in vitro and in vivo. PLoS ONE 2012, 7, e37242. [CrossRef] [PubMed]

21. Kirsch, M.I.; Hulseweh, B.; Nacke, C.; Rulker, T.; Schirrmann, T.; Marschall, H.J.; Hust, M.; Dubel, S. Development of human antibody fragments using antibody phage display for the detection and diagnosis of venezuelan equine encephalitis virus (veev). BMC Biotechnol. 2008, 8, 66. [CrossRef] [PubMed]

22. Jager, V.; Bussow, K.; Wagner, A.; Weber, S.; Hust, M.; Frenzel, A.; Schirrmann, T. High level transient production of recombinant antibodies and antibody fusion proteins in hek293 cells. BMC Biotechnol. 2013, 13, 52. [CrossRef] [PubMed]

23. Froude, J.W.; Pelat, T.; Miethe, S.; Zak, S.E.; Wec, A.Z.; Chandran, K.; Brannan, J.M.; Bakken, R.R.; Hust, M.; Thullier, P.; et al. Generation and characterization of protective antibodies to marburg virus. MAbs 2017, 9, 696-703. [CrossRef] [PubMed]

24. Phelps, A.L.; O'Brien, L.M.; Eastaugh, L.S.; Davies, C.; Lever, M.S.; Ennis, J.; Zeitlin, L.; Nunez, A.; Ulaeto, D.O. Susceptibility and lethality of western equine encephalitis virus in balb/c mice when infected by the aerosol route. Viruses 2017, 9. [CrossRef] [PubMed]

25. Ko, S.Y.A.W.; Yang, E.S.; Kong, W.P.; Burke, C.W.; Honnold, S.P.; Nichols, D.K.; Schieber, G.L.; Carlton, K.; DaSilva, L.; Traina-Dorge, V.; et al. A trivalent virus-like particle vaccine protects against diverse equine encephalitis viruses in non-human primates. Manuscript in preparation, 2018.

26. Reichert, E.; Clase, A.; Bacetty, A.; Larsen, J. Alphavirus antiviral drug development: Scientific gap analysis and prospective research areas. Biosecur. Bioterror. 2009, 7, 413-427. [CrossRef] [PubMed]

27. Schmaljohn, A.L.; Johnson, E.D.; Dalrymple, J.M.; Cole, G.A. Non-neutralizing monoclonal antibodies can prevent lethal alphavirus encephalitis. Nature 1982, 297, 70-72. [CrossRef] [PubMed]

28. Parker, M.D.; Buckley, M.J.; Melanson, V.R.; Glass, P.J.; Norwood, D.; Hart, M.K. Antibody to the e3 glycoprotein protects mice against lethal venezuelan equine encephalitis virus infection. J. Virol. 2010, 84, 12683-12690. [CrossRef] [PubMed]

29. Forthal, D.N. Functions of antibodies. Microbiol. Spectr. 2014, 2, AID-0019-2014. [CrossRef] [PubMed]

30. Mayr, L.M.; Su, B.; Moog, C. Non-neutralizing antibodies directed against hiv and their functions. Front. Immunol. 2017, 8, 1590. [CrossRef] [PubMed]

31. Reed, D.S.; Glass, P.J.; Bakken, R.R.; Barth, J.F.; Lind, C.M.; da Silva, L.; Hart, M.K.; Rayner, J.; Alterson, K.; Custer, M.; et al. Combined alphavirus replicon particle vaccine induces durable and cross-protective immune responses against equine encephalitis viruses. J. Virol. 2014, 88, 12077-12086. [CrossRef] [PubMed] 
32. McClain, D.J.; Pittman, P.R.; Ramsburg, H.H.; Nelson, G.O.; Rossi, C.A.; Mangiafico, J.A.; Schmaljohn, A.L.; Malinoski, F.J. Immunologic interference from sequential administration of live attenuated alphavirus vaccines. J. Infect. Dis. 1998, 177, 634-641. [CrossRef] [PubMed]

33. Reisler, R.B.; Gibbs, P.H.; Danner, D.K.; Boudreau, E.F. Immune interference in the setting of same-day administration of two similar inactivated alphavirus vaccines: Eastern equine and western equine encephalitis. Vaccine 2012, 30, 7271-7277. [CrossRef] [PubMed]

34. Burke, C.W.P.A.I.; Erwin-Cohen, R.; Eccleston, L.T.; Fitzpatrick, C.J.; Glass, P.J. A multi-agent alphavirus replicon particle vaccine is immunogenic and provides proection against western equine encephalitis disease in non-human primates. Manuscript in preparation, 2018.

35. Gardner, C.L.; Sun, C.; Luke, T.; Raviprakash, K.; Wu, H.; Jiao, J.A.; Sullivan, E.; Reed, D.S.; Ryman, K.D.; Klimstra, W.B. Antibody preparations from human transchromosomic cows exhibit prophylactic and therapeutic efficacy against venezuelan equine encephalitis virus. J. Virol. 2017, 91. [CrossRef] [PubMed]

36. Kugelman, J.R.; Kugelman-Tonos, J.; Ladner, J.T.; Pettit, J.; Keeton, C.M.; Nagle, E.R.; Garcia, K.Y.; Froude, J.W.; Kuehne, A.I.; Kuhn, J.H.; et al. Emergence of ebola virus escape variants in infected nonhuman primates treated with the mb-003 antibody cocktail. Cell. Rep. 2015, 12, 2111-2120. [CrossRef] [PubMed]

37. Chem, Y.K.; Chua, K.B.; Malik, Y.; Voon, K. Monoclonal antibody-escape variant of dengue virus serotype 1: Genetic composition and envelope protein expression. Trop. Biomed. 2015, 32, 344-351. [PubMed]

38. Matsuzaki, Y.; Sugawara, K.; Nakauchi, M.; Takahashi, Y.; Onodera, T.; Tsunetsugu-Yokota, Y.; Matsumura, T.; Ato, M.; Kobayashi, K.; Shimotai, Y.; et al. Epitope mapping of the hemagglutinin molecule of a/(h1n1)pdm09 influenza virus by using monoclonal antibody escape mutants. J. Virol. 2014, 88, 12364-12373. [CrossRef] [PubMed]

39. Pal, P.; Fox, J.M.; Hawman, D.W.; Huang, Y.J.; Messaoudi, I.; Kreklywich, C.; Denton, M.; Legasse, A.W.; Smith, P.P.; Johnson, S.; et al. Chikungunya viruses that escape monoclonal antibody therapy are clinically attenuated, stable, and not purified in mosquitoes. J. Virol. 2014, 88, 8213-8226. [CrossRef] [PubMed]

40. Lee, C.Y.; Kam, Y.W.; Fric, J.; Malleret, B.; Koh, E.G.; Prakash, C.; Huang, W.; Lee, W.W.; Lin, C.; Lin, R.T.; et al. Chikungunya virus neutralization antigens and direct cell-to-cell transmission are revealed by human antibody-escape mutants. PLoS Pathog. 2011, 7, e1002390. [CrossRef] [PubMed]

(C) 2018 by the authors. Licensee MDPI, Basel, Switzerland. This article is an open access article distributed under the terms and conditions of the Creative Commons Attribution (CC BY) license (http:/ / creativecommons.org/licenses/by/4.0/). 